\title{
THE BRIBED CONGRESSMAN'S IMMUNITY FROM PROSECUTION
}

ThE Constitution promotes free discussion in Congress through a provision that "for any Speech or Debate in either House, [Members of Congress] shall not be questioned in any other place."1 During the present term, the Supreme Court will consider for the first time whether this clause bars prosecution of a Congressman who received money for delivering a speech on the floor of the House.?

The Government indicted Congressman Thomas F. Johnson on eight counts for receiving compensation from, and performing services for, certain Maryland savings and loan institutions. The first count charged a violation of a statute making it a crime to conspire "to defraud the United States." 3 The conspiracy consisted of an attempt to influence the Justice Department's conduct of pending mail fraud proceedings and the delivery of a speech in the House favorable to the Maryland bankers. Johnson's activities allegedly defrauded the United States of "its right to have the lawful functions and duties of the defendant ... free from corruption...." The remaining seven counts charged that Johnson's intervention before the Justice Department violated a conflict of interest statute. ${ }^{5}$ The jury found the defendant guilty on all counts. ${ }^{6}$ The Fourth Circuit Court of Appeals concluded that the speech or debate clause barred prosecution of a Congressman who accepted a bribe to deliver a speech. The court therefore dismissed the conspiracy count and ordered a new trial of the seven conflict of interest counts on the theory that the introduction of evidence relating

1. U.S. ConsT., art. I, § 6.

2. United States v. Johnson, 337 F.2d 180 (4th Cir. 1964), cert. granted, 379 U.S. 988 (1965).

3. 18 U.S.C. § 371 (1958).

4. 337 F.2d 180, 184. The speech in issue was delivered on June 30, 1960. Johnson declared in the course of defending Maryland's independent savings and loan industry that:

I personally do not know any of these indicted institutions, nor any of the circumstances leading to their respective indictments. I hold no bricf for any of them one way or another. ...

I have sought in these remarks to be entirely objective with respect to the pros and cons of this situation.

106 CoNG. Rec. $15258-15259$ (1960).

5. 18 U.S.C. $\S 203$ (1964) (formerly 62 Stat. 697 (1948), 18 U.S.C. $\S 281$ (1958).

6. United States v. Johnson, 215 F. Supp. 300 (D. MId. 1963). 
to the bribed speech prejudiced the jury's consideration of the conflict of interest charges.

The holding of the Court of Appeals was internally inconsistent. Although the Court prohibited prosecution for receiving money to make a speech, it allowed prosecution for receiving money to intervene before the Justice Department. But in previous civil cases, courts have broadly defined the protective scope of the constitutional provision as embracing "every ... act resulting from the nature, and in the execution, of the office."7 Intervention before an executive department is certainly in the nature and execution of the congressional office. ${ }^{8}$ Therefore, if the free speech or debate clause had been invoked in its accepted scope, all of the counts against Johnson should have been dismissed. If Johnson leads to the use of the clause in its accepted scope, then the case may be the first step in establishing a comprehensive prohibition on criminal prosecutions of Congressmen.

The Fourth Circuit advanced five reasons in support of its decision. First, the court looked to the origin of the clause in English constitutional history as a protection for members of Parliament from punishment by any agency other than Parliament itself. The second argument supporting the decision was the impropriety of judicial inquiry into the motives of legislators. Third, the court transferred the principle of absolute immunity developed in libel and slander cases to the context of criminal prosecution for bribery. A final pair of arguments advanced by the Fourth Circuit was the possibility of abuse of executive prosecutorial discretion and the availability of legislative sanctions by which Congress is able to punish its own members.

The court's construction of the free speech or debate clause began with a consideration of the ancestry of the clause in the privilege of the English Parliament to be free from outside influences which might affect the course of debate or legislation. ${ }^{\circ}$ The evolution of the English privilege mirrored the continuing constitutional struggle between Crown and Parliament which culminated in the "Glorious Revolution." In the ninth article of the Bill of Rights which resulted, the privilege received final statutory confirmation by a provision "that the freedom of speech and debates or proceedings in Parliament ought

7. Coffin v. Coffin, 4 Mass. 1, 27 (1808); cited with approval in Tenney v. Brandhove, 341 U.S. 367,374 (1951).

8. In applying 18 U.S.C. $\$ 281$, a court ruled in May v. United States, 175 F.2d 994,1006 (D.C. Cir. 1949), that a Congressman who received compensation for his serviccs beforc an agency was guilty of an illegal act even though he acted ". . . within the scope of his official duties as a Congressman."

9. Wittke, The History of Englisi Parliamentary Privilege 30 (1921). 
not to be impeached or questioned in any court or place out of Parliament."10 In America, the colonial assemblies were patterned after the English Parliament and claimed the privilege of free speech and debate. ${ }^{11}$ Several state constitutions ${ }^{12}$ and the Articles of Confederation $^{13}$ incorporated the immunity, and the privilege was adopted without opposition or meaningful debate at the Constitutional Convention. ${ }^{14}$

Although the American speech or debate provision is the descendent of the English privilege, the differing positions of Parliament and Congress in their respective political systems has led to a divergence of the privilege in the two countries. The absolute supremacy of the English Parliament, particularly as reflected by its tradition as the Highest Court of the Realm, ${ }^{15}$ has sharply limited judicial review, ${ }^{10}$ whereas the American Congress is but a coordinate branch of government. When Parliament, for example, finds a breach of its privilege that its speech or debate shall not be questioned, even in mere political criticism, ${ }^{17}$ it can imprison the offender for contempt and no court can

10. 1 W. \& M., c. 2, art. 9 (1688). Once the privilege received formal recognition, the Grown employed bribery to subvert a supposedly independent Parlinment. Both William III and Queen Anne increased the number of royal offices available for their support in Parliament and made direct payments to members. Srapkins AND TVRuTH, Corruption IN Deveroping Countries 78 (1963). See generally ANson, LAw aNd Custom of tire Constrtu. TIoN 369-76 (5th ed. 1922). The system reached its peak under George III who resorted to wholesale and public bribery to muster support for his colonial policy. Surpasis AND WrATT, op. cit. supra at 82. In one famous instance, the King and his "bought" Parlinment were arrayed against the electorate and a single member, John Wilkes, who had attacked certain statements made by the Crown. In addition to prosecuting W'illics for libel, the King urged Parliament several times to expel Wilkes as the electorate continued to return him as a member. WrTrk, op. cit. supra note 9, at 115-23. The incident indieates in dramatic fashion that the bribery of members not only undermined the privilege but also frustrated the representative character of Parliament. Historically, then, the bribery of members was antithetical to the freedom of speech and debate in Parliament.

11. Clarke, Parliamentary Prinlege in the American Colonies 12 (1943).

12. Maryland Deciaration of Righrs, art. VUII (1776); MLAss. Const., part I, art. XXI (1780); N.H. CoNST., part I, art. XXX (1784).

13. ARticles of Confederation, art. 5.

14. 2 FARRaNd, ThE Recordos of the Federal Convention 254, 567, 593 (1937). Charles Pincleney and Madison disagreed as to whether "provision should be made for ascerkining by law the privileges of each house, rather than allowing each house to decide for itself" Butzaner, Constirutional Chaff 47 (1941).

15. WrITKE, op. cit. supra note 9 , at 13.

16. "The decisions of the courts are not accepted as binding by the House in matters of privilege, nor the decision of the House by the courts. Thus the old dualism remains unresolved." May, The Law, Privineges, Procefongas and Usage of Parlumient 173 (17th ed. 1964).

17. Thus the Speaker of the House of Commons recently found a "prima facie" breach of privilege in a suggestion by the Chancellor of the Exchequer that certain 
review its decision. ${ }^{18}$ But the Supreme Court has declared that powers and privileges of the House of Commons on the subject of contempt have no application to the Congress. ${ }^{10}$ An act must obstruct the legislative process before the Congress can invoke contempt power. ${ }^{20}$ And even then there can be judicial review. ${ }^{21}$ The difference between Eng. lish parliamentary privilege and congressional privilege suggests that Parliament's historic reservation of the sole right to punish its members for accepting bribes in the discharge of their office ${ }^{22}$ should not be conclusive in determining whether courts should be denied jurisdiction under the speech or debate clause of the American Constitution.

In two countries where provision for legislative free speech or debate exists but where the legislature may not claim a tradition as the high. est court of the realm, ${ }^{23}$ courts have held that the privilege does not bar the criminal prosecution of legislators for bribery. Two Australian and a single Canadian case posed the issue. Regina $v$. White ${ }^{24}$ held only that an attempt to bribe a member of Parliament was a misdemeanor at common law. But counsel for White had argued that since "the court had no jurisdiction to inquire into the mode in which members of Parliament voted, or their reasons for voting in any particular way," it could not entertain a prosecution against one who offered to bribe a legislator. In upholding White's conviction, the court dismissed the argument of counsel and declared that a legislator who accepted a bribe was guilty of a common-law offense. ${ }^{26}$ In Rex $v$. Boston, ${ }^{27}$ an Australian

members represented financial interests. N.Y. Times, July 11, 1965, § E, p. 4, col. 1. The mere threat to begin a libel action against a member may constitute a breach of privilege. See Van Heuston, Parliamentary Privilege, in Essıys in Constrturionıt Lıw 82, 95-98 (1964).

18. I Schwartz, The Powers of Government 124 (1963); Compare Anderson v. Dunu, 19 U.S. (6 Wheat.) 204 (1821).

19. Kilbourn v. Thompson, 103 U.S. 168, 189 (1881).

20. Jurney v. MacCracken, 294 U.S. 125, 148 (1935).

21. Kilbourn v. Thompson, 103 U.S. 168 (1881).

22. Parliament regards the act as inconsistent with the maintenance of the privllege of free speech or debate. MAY, op. cit. supra n.16, at 52, 115-116.

23. See Kielley v. Carson, 4 Moo. P.C. 63, 89, 13 Eng. Rep. 225, 295 (1842), per Parke, B.,

[T] he reason why the House of Commons has this [broad contempt] power, is not because it is a representative body with legislative functions, but by virtue of ancient usage and prescription; the lex et consuetudo Parliamenti, which forms a part of the Common Law of the land, and according to which the High Court of Parliament, before its division, and the Houses of Lords and Commons since, are invested with many peculiar privileges, that of punishing for contempt being onc.

24. 13 N.S.W. Sup. Ct. 322 (1875).

25. Id. at 324 .

26. Id. at 339 .

27. 33 Commw. L.R. 386 (1923). 
court held that acceptance of money by a member of the legislative assembly of New South Wales in exchange for a promise to induce the government to purchase certain estates was a criminal offense. The court accepted on principle the proposition that a legislator could be prosecuted for a "bribed" vote. ${ }^{28}$ In the Canadian case, Regina $v$. Bunting, ${ }^{29}$ the defendants made the same claim as the defendants made in Rex $v$. White, that the legislature had exclusive jurisdiction to punish anyone for bribing a legislator. Chief Justice Wilson, writing one of two majority opinions, rejected this argument and also found the "proposition very clear" that the courts have jurisdiction over a member who accepts a bribe "in respect of any of his duties as a member of [the] Assembly."30 The refusal of these courts to recognize the English privilege as a bar to criminal prosecution of legislators for bribery suggests that this aspect of the privilege depends upon the unique position and tradition of the English Parliament.

The Fourth Circuit supported its use of the English history by relying upon the doctrine of judicial deference to the motives of legislators. In recent years, this doctrine has cropped up in controversies regarding the right of legislators to make accusations of subversive activities. $^{31}$ The leading case is Tenny $v$. Brandhove, ${ }^{32}$ in which the plaintiff brought suit under a 1871 civil rights statute against the members of a California Senate committee charged with investigating subversive activities. A nearly unanimous court speaking through Justice Frankfurter referred to the speech or debate clause in federal and state constitutions in holding that Congress did not intend to make legislators liable for injuring a witness through committee investigation. ${ }^{33}$ The historic basis of the privilege was said to be the principle that "the

28. The dispute centered on whether Boston was acting as a legislator, as lic indict. ment charged, when he attempted to use his influence outside Parliament. Id. at 392.

29. 7 Ont. Rep. 524 (1885).

30. Id. at 542 .

31. See generally Yankwich, Immunity of Congressional Speech, 99 U. PA. L. REv. 950 (1951); and Oppenheim, Congressional Free Speech, 8 LorolA L. REv. (1950). For Gses which relate the privilege to legislative investigations, see Yellin v. United States, 37t U.S. 109, 122 (1963); and Barsky v. United States, 167 F.2d 241, 250 (D.C. Cir. 1918). cert. denied, 334 U.S. 843 (1948). Methodist Federation for Social Action v. Enstland, I4l F. Supp. 729, 731 (D.C.D.C. 1956).

32. 341 U.S. 367 (1951).

39. Justice Frankfurter concluded his opinion with a carcat, emphasizing that his discussion of the privilege applied only to the facts of that case. Id. at 378-79. Justice Black concurred. Id. at 379. Justice Douglas, alone in dissent, urged: "It is one thing to give great leeway to the legislative right of speech, debate and investigation. But when a committee perverts its power ... for [a] . . corrupt purpose, the reason for the immunity ends." $I d$. at 383 . 
legislature must be free to speak and act without fear of criminal and civil liability." 34 Frankfurter reasoned further that judicial deference to the legislative branch supported the privilege even in the face of an allegation of unworthy purpose:

The claim of an unworthy purpose does not destroy the privilege. ... The holding of this Court in Fletcher $v$. Peck, 6 Cranch 87, 130 [1810], that it was not consonant with our scheme of government for a court to inquire into the motives of legislators, has remained unquestioned..$^{35}$

Therefore, the Court held that the privilege insulated the legislators from liability for the conduct of the investigation.

The Fourth Circuit assumed that the theory of judicial deference expressed in the Tenney opinion was applicable to the Johnson situation. The impropriety of judicial inquiry into the motives of legislators is rooted in the separation of powers doctrine and dates back to the case of Fletcher v. Peck ${ }^{36}$ in which Chief Justice Marshall refused to inquire into the motives of a legislature whose members had allegedly been bribed to secure passage of an act. Inquiry into the motives of legislators responsible for the enactment of a law is concededly inadvisable (if not impossible) since the stability of statute law would be impaired if the good or bad intentions of individual members became a criterion for judging validity. The passage of a statute, moreover, is the work of the legislature as a responsible branch of government about whose operation assumptions of legitimacy should be made..$^{37}$ Deference to the formal enactment of an institution does not, however, justify similar respect for the motives of individual officials. ${ }^{38}$ From a practical standpoint, moreover, the insuperable difficulties of proof involved in investigating the motives of representatives responsible for the enactment of a statute are not duplicated when the object of investigation is a single legislator. ${ }^{39}$ In deferring to the sanctity of legislative motive, the Fourth Circuit failed to make the relevant discrimination between an act of Congress and an act of one of its members.

An attitude of judicial deference is decidedly inappropriate when

34. Id. at 375 .

35. Id. at 377, quoted in Johnson, 337 F.2d at 188.89 .

36. 10 U.S. (6 Cranch) 87 (1810).

37. Bickel, The Least Dangerous Brancil 214 (1962).

38. See Black, Perspectives in Constitutional Law 4-5 (1963).

39. The undertaking is certainly easier than the discovery of the motives for a legisla. tive investigation, a task which some members of the Supreme Court have not hesitated to assume in recent years. Barenblatt v. United States, 360 U.S. 109, 153, 166 (1959); Wilkinson v. United States, 365 U.S. 399, 429 (1961). 
Congress has directed the courts to exercise jurisdiction. For more than one hundred years Congress has delegated to the courts the responsibility for trying legislators accused of accepting bribes. ${ }^{40}$ And in the 1962 revision of the conflict of interest statutes, ${ }^{11}$ Congress responded to increased national concern over the ethical standards of political officials by reaffirming and broadening this delegation of authority to the courts. ${ }^{42}$

The third support for the Fourth Circuit's holding in Johnson was the existing English and American case law which has applied the privilege chiefly as a shield for legislators against libel and slander

40. A statute passed in 1853 declared a member "liable to indictment as for a high crime and misdemeanor in any court of the United States" for accepting compensation intended to influence a "vote or decision on any question ... brought before him in his official capacity ...." Act of Feb. 26, 1853, ch. 81, $\$ 6,10$ Stat 171. A supporter of the bill indicated in debate that a provision for forfeiture of office upon conviction had been deleted because of doubts as to its constitutionality. 26 CoNic. Grone, 32d Cong., 2d Sess. 392 (1853). But no member questioned the constitutionality of the criminal provision. (The language of the statute reminds one of the juxtaposition of "high crime or misdemeanor" with bribery found in U.S. CoNST. art. II, § 4-the impeachment provision-demonstrating, it would seem, the seriousness with which the framers of the statute, at least, regarded the offense.)

The procurement frauds of the Civil War led Congress to enact two more statutes dealing with the bribery of members. An 1862 statute, Act of July 16, 1862, ch. 180 , 12. Stat. 577, which remained substantially unchanged until 1962, 18 U.S.C. $\$ 205$ (1958) (now 18 U.S.C. $\S 201$ (1964)) also delegated to the courts the power to punish venal Congressmen. As Senator Roscoe Conkling noted in floor discussion of the measure, it was intended to penalize legislators who received "pay for votes or influence in any" matter pending before Congress." 42 ConG. Globe pt. 4, 37th Cong,, 2d Sess. 3260 (1862). An 1864 conflict of interest statute, the predecessor to 18 U.S.C. $\S 281$ (1958), barred Congressmen from receiving compensation for their services before any agency. Act of June 11, 1864, ch. 119, 13 Stat. 123 (now 18 U.S.C. $\$ 203$ (1964)). Although the question of whether services rendered in Congress violate $\S 281$ has not been resolved by the courts, one commentator has pointed to the impressive policy argument that "Congress could not have intended that its members ... should be free to acopt from private sources compensation for lobbying in favor of private-interest legislation and claims in the Congress. . ." Manning, Federal Conflict of Interest Law 63 (1964). These statutes would seem to offer persuasive evidence of congressional intent to delegate to the courts the responsibility for trying legislators accused of accepting bribes.

41. 76 Stat. 1119; 18 U.S.C. $\$ \S 201-18$ (1964). The Ievision followed upon a lengthy study by an eminent committee of the New York City Bar, ThE Associntion of miE Bar OF THE CITY OF NEW YORK, CONFLICT OF INTEREST ANd FEDERAL SERvice (1960), and reports by committees of both Houses of Congress. H. REP. No. 748, 87th Cong., lst Sess. (1961); S. REP. No. 2213, 87 Cong., 2d Sess. (1962).

42. The new statute designates a member of Congress as a "public official" and defines the "official act" in sweeping terms as:

any decision or action on any question ... which may ... be brought before any"

public official, in his official capacity, or in his place of trust. . . .

18 U.S.C. \$ 201(a) (1964). The language would seem to be as broad as the scope given to the speech or debate clause. 
actions. Two leading English cases establish the broad immunity conferred by the privilege against such suits. In Stockdale $v$. Hansard, ${ }^{40}$ the Court of Queen's Bench held that the defendant, who published a libelous report under order of the House of Commons, but who was not a member of Parliament, could not avail himself of the privilege. The Court also declared that:

For speeches made in Parliament by a member to the prejudice of any other person, or hazardous to the public peace, the member enjoys complete impunity. ${ }^{44}$

This frequently quoted dictum ${ }^{45}$ was reinforced by the decision in Ex parte Wason. ${ }^{46}$ The Court of Queen's Bench there upheld a magistrate's refusal to issue an indictment against two peers for allegedly conspiring to deceive the House of Lords by making false statements concerning the author of a petition submitted to that body. "Statements made by members ... however injurious they might be to the interest of a third person," 47 the Chief Justice said, could not be the subject of a criminal prosecution.

The three leading American cases have also firmly established the absolute immunity of congressional speech from libel or slander actions. In Coffin v. Coffin, ${ }^{48}$ Chief Justice Parsons of the Massachusetts Supreme Court, while holding that the privilege did not protect a member from a civil suit when the alleged slander was made in a casual remark in the chamber of the legislature, declared that the privilege ought to be construed liberally to embrace "every ... act resulting from the nature, and in the execution, of the [legislator's] office." 40 The Supreme Court in Kilbourn v. Thompson ${ }^{50}$ quoted with approval the Massachusetts court's description of the privilege, and held that an action for false imprisonment would not lie against a Congressman who issued a report or voted for a contempt resolution. Finally, Cochran v. Couzens ${ }^{51}$ held that words even if uttered maliciously need not be pertinent or relevant to the subject before the chamber in order to fall under the cloak of privilege.

\footnotetext{
43. 9 Ad. \& E. 1, 112 Eng. Rep. 1112 (Q.B. 1939). The decision was repealed onc year later by the Parliamentary Papers Act which gave summary protection to atthorized publishers of parliamentary papers. $3 \& 4$ Vict., c. 9.

44. Id. at 1156 .

45. E.g., in United States v. Johnson, 337 F.2d at 187.

46. 4 Q.B. 573 (1869); cf. Dillon v. Balfour, 20 L.R. Ir. 600 (1887).

47. 4 Q.B. at 576.

48. 4 Mass. 1 (1808).

49. Id. at 27.

50. 103 U.S. 168 (1880).

51. 42 F.2d 783 (D.C. Cir. 1930), cert. denied, 282 U.S. 874 (1980).
} 
In the language of the law of defamation, the speech or debate clause establishes an absolute privilege, that is, an immunity which cannot be overcome by showing of malice.52 Although the Constitution incorporates only a legislative privilege of unquestioned speech or debate, the common law traditionally extends an absolute immunity from libel and slander actions to executive and judicial officials as well. ${ }^{53}$ The immunity of judges from civil suits resulting from official acts affords the earliest application of the rule. ${ }^{\text {st }}$ Executive officials, including a naval commander, ${ }^{55}$ the Postmaster General, ${ }^{50}$ and the Attorney General, ${ }^{57}$ have successfully invoked the absolute privilege as a defense to civil suit. And in a recent case, the Supreme Court indicated the similarity of executive and legislative absolute privilege by citing Tenney to support a holding that the director of the Office of Rent Stabilization could announce with absolute immunity the suspension of subordinate employees for the misuse of funds. ${ }^{68}$ Absolute privilege, moreover, has not seen service solely at the federal level. Many state constitutions contain provisions conferring immunity upon the operations of their assemblies, ${ }^{89}$ and state courts have held absolute privilege applicable not only to legislative but also to executive and judicial proceedings at both the state ${ }^{00}$ and local levels. ${ }^{01}$

52. Note, Developments in the Law-Defamation, 69 HARv. L. REv. 875, 917-18 (1956). For a statement of the distinction between absolute and qualified privalege, sce Bigelow v. Brumley, 138 Ohio St. 574, 579, 37 N.E.2d 584, 588 (1941).

53. Courts often discuss absolute privilege in general terms, noting simply that a constitutional provision protects legislators, e.g., Walker v. D'Alesandro, 212 Mrd. 163. 169-70, 129 A.2d I48, 151 (1957).

54. Van Vechten Veeder, Absolute Immunity in Defamation: Judicial Proccedings, 9 Colum. L. REv. 463, 483 (1909). It should be remembered that the English Parliament originally claimed absolute privilege as the Figh Court of Parliament, sce note 15, supra, and that the colonial legislators have been described as little Parliaments because of their pretensions to judicial authority. See note 11 supra. In this country the immunity of judges from civil suit for official acts has long been recognized. Bradley v. Fisher, 80 U.S. (13 Wall.) 335 (1871); Alzua v. Johnson, 231 U.S. 106 (1913).

55. Howard v. Lyons, 360 U.S. 593 (1959).

56. Spalding v. Vilas, 161 U.S. 483 (1896).

57. Gregoire v. Biddle, 177 F.2d 579 (2d Cir. 1949).

58. Barr v. Matteo, 360 U.S. 564, 575 (1959).

59. Forty-one states have such a provision. See Tenney v. Brandhove, 341 U.S. 367 , 375-76 n.5 (1951).

60. Van Riper v. TumuIty, 26 N.J. Misc. 37, 56 A.2d 611 (1948) (legislator); Matson v. Margiotti, 371 Pa. 188, 88 A.2d 892 (1952) (attorney general); Ginger v. Wayne Circuit Judge, 369 Mich. 680, 120 N.W.2d 842 (1963) (circuit judge).

61. "... the rule that publication of defamatory matter in the due course of legislative proceedings is absolutely privileged .... includes all such proceedings, whether federal, state or municipal." Larson v. Doner, 32 Ill. App. 2d 471, 178 N.E.2d 399, 401 (1961) (city mayor and commissioners); Shade v. Bowers, 199 N.E.2d 131 (Ohio CL. C.P. 
Despite the acceptance of the constitutional or common law absolute privilege as a bar to civil actions against all officials, the privilege has never, until Johnson, been invoked as a bar to criminal prosecution for bribery. The absolute immunity from civil liability resulting from the statements of federal judicial and executive officials does not insulate them from criminal liability for their venal acts. ${ }^{02}$ Similarly, statutes in almost all states make the acceptance of compensation by judicial, executive, or legislative officials ${ }^{03}$ from private individuals a criminal offense. The same states, as has been noted, have constitutional provisions similar to the speech or debate clause in the United States Constitution. ${ }^{84}$

The reason the absolute privilege has not been extended to bar criminal prosecutions for bribery is that the policy justifications underlying civil immunity do not apply to criminal prosecutions. The justification for granting to officials an absolute immunity from libel or slander actions is essentially the fear that honest speech might become the basis of liability if a showing of malice could defeat the privilege. Malice has been defined as "any improper motive" and as falsifying with good motives. ${ }^{65}$ Even if the defendant official possessed an honest belief in the truth of what he has said, it has been held that a showing of ill will or spite suffices to prove malice. Exaggeration or

1962) (village mayor and chief of police); Karelas v. Baldwin, 237 App. Div, 265, 261 N.Y.S. 518 (1932) (justice of the peace). Some courts do not extend the privilege to subordinate legislative bodies or inferior executive officers. See generally, 1 HAnu'er \& James, The Law of Torts $428-39$ (1956), and Prosser, Torts 800.09 (3rd cd. 1964).

62. United States v. Manton, 107 F.2d 834 (2d Cir. 1938) (defendant was the Scnior Circuit Judge of the United States Court of Appeals for the Second Circuit). Fall v. United States, 49 F.2d 506 (D.C. Cir.), cert. denied, 283 U.S. 867 (1981) (Scerctary of the Interior). The Constitution also makes it clear that such officials are not immune from prosecution. U.S. ConsT. art. I, § 3.

63. Just as absolute privilege extended first to judicial officials, early state court decisions indicate that the common law conception of bribery was originally limited to corruption in the administration of justice. Cf. Commonwealth v. Funk, $314 \mathrm{Ky} .282$, 284-85, 234 S.W.2d 957, 959 (1950); People v. Patillo, 386 Ill. 566, 572.73, 54 N.E.2d 518, 551-52 (1944). The modem definition extends to all officials concerned with the administration of government, including legislators. Perkins, Criminal LAW 898 (1957). For an enumeration of the states which provide by statute that the acceptance of compensation by legislators from private individuals is a criminal offense, see United States v. Johnson, 215 F. Supp. 300, 306-07 n.6 (1963).

64. See Tenney v. Brandhove, 341 U.S. $367,375.76$ n.5 (1951). State legislators have never raised the privilege as a defense to a bribery prosccution. Sims v. State, 181 Ark. 185, 198 S.W. 883 (1917) (vote); People v. Bunkers, 2 Cal. App. 197, 84 Pac. 364 (1905) (investigation); People v. Logie, 321 Mich. 303, 32 N.W.2d 458 (1948) (committce votc); State v. Ivanhoe, 238 Mo. App. 200, 177 S.W.2d 657 (1944) (vote); Cox v. State, 166 Tex. Crim. 587, 316 S.W.2d 891 (1958) (vote).

65. 1 HARPER \& JAMEs, op. cit. supra note 61, at 452. 
vehemence of language, moreover, may furnish evidence of ill will." And most troublesome of all, a jury may find that an absence of reasonable grounds for belief in the truth of a statement, however genuine that belief may have been, satisfies the requirements of malice. ${ }^{.7}$ Thus, broad definitions of malice and the difficulty of controlling juries necessitate an absolute immunity from libel and slander actions if nonmalicious speech is not to be deterred.

Before the absolute immunity developed in defamation cases can be invoked as a bar to criminal prosecution, ${ }^{08}$ it must appear that the possibility of criminal prosecution for bribery would inhibit honest speech. The dampening effect of amenability to criminal prosecution depends upon the extent to which a Congressman proceeding in good faith will be deterred by either the possibility of conviction or by the threat of a politically motivated indictment.

The possibility of an innocent Congressman being convicted for bribery is less than the possibility of a well-meaning Congressman being found liable for malicious defamation. The standard of proof is, of course, more stringent in the criminal case: a mere preponderance of evidence will not suffice. The prosecutor must prove the elements of a crime beyond a reasonable doubt. ${ }^{69}$ And in a bribery prosecution, in contrast to an action for malicious defamation, the speech alone may not be the basis for liability; the inquiry focuses on whether the speech was given in return for compensation. ${ }^{70}$

66. Newark Trust Co. v. Bruwer, 51 Del. (1 Storey) 188, 141 A.2d 615 (1958); Prosses, op. cit. supra note 61 , at 822 .

67. I HARPPR \& JAMIEs, op. cit. supra note 61 , at 453 .

68. The Fourth Gircuit was mistaken in its basic assumption that Johnson could have invoked an absolute privilege in a hypothetical libel or slander action. Inquiry into motive is permissible in libel actions against Congressmen who have distributed copies of the allegedly libellous speech, for only a qualified privilege attaches to statements which a Congressman disseminates for his private use. "[T]he absolute privilege to inform a fellow legislator . . . becomes a qualified privilege for the republication of the information .... Congressmen ... are liable for malicious defamation, for the unofficial dissemination of the Congressional Record." McGovern v. Mfartz, 182 F. Supp. 343, 347-48 (D.D.C. 1960). See also Long v. Ansell, 69 F.2d 386, 389 (dictum), aff'd, 293 U.S. 76 (1934); The King v. Creevy, 1 M. \& S. 273, 105 Eng. Rep. 102 (K.B. 1813).

In Johnson, evidence indicated that the defendant-Congressman caused the distribution of 50,000 copies of his speech to customers of the Maryland savings and loan companics. Thus, if it were suitable to transfer the principles of libel and slander ases to the Johnson situation, the Fourth Circuit failed to recognize the principle appropriate for uransfer.

69. A trial judge must direct a verdict for the accused if he belicves that the jur' could not reasonably find that the evidence of the prosecution excluded "every other hypothesis but that of guilt." Isbell v. United States, 227 Fed. 783, 792 (Bth Cir. 1915). Cf. United States v. Masiello, 235 F.2d 279, 285 (2d Cir. 1956) (concurring opinion of Frank, J.).

70. Under the predecessor of 18 U.S.C. 281 , it was held that an innocent motive for 
Of course, a vaguely defined offense might inhibit honest congressional speech and might therefore necessitate application of the principle of absolute immunity developed in defamation cases. A vague statute allows the prosecutor latitude to define the offense. ${ }^{71}$ This discretion amplifies the danger of politically motivated prosecutions. Also, the imprecise nature of an offense could make a conviction much easier to obtain. For example, the indictment involving Congressman Johnson's speech was brought under 18 U.S.C. \$ 371, the "Conspiracy to Defraud the United States" statute. Under this statute an agreement to accomplish any fraudulent purpose constitutes, without more, the foundation for criminal liability. ${ }^{2}$ The usual requirement of proving an act in addition to a criminal intent is undercut by the need of proving only an agreement in conspiracy prosecutions. ${ }^{73}$ The Fourth Circuit, therefore, would have been justified in finding that the deterrent effect resulting from the vagueness of the conspiracy statute warranted application of the principle of absolute immunity developed in defamation cases.

Using similar reasoning, the court should also have invalidated the prosecution under the conflict of interest statute for intervention before the Justice Department. The speech or debate clause should encompass all the representative functions which a modern Congressman performs. ${ }^{74}$ Although speech is classically the basic element of the legislative process, today it may be less significant than a Congressman's accepted practice of interceding before government agencies on behalf of his constituents, to obtain or provide information, to press for change in policy, and generally to perform a supervisory function. ${ }^{76}$ If the constitutional provision covers intervention before the Justice Department as well as speech, the vagueness analysis which supports the invalidation of the conspiracy prosecution also supports invalidating the prosecution under the conflict of interest statute. This statute, 18 U.S.C. $§ 281$, fails to define an offense which predicates guilt upon

an act would not exculpate the defendant if he accepted compensation for its perform. ance since "criminal intent . . . may be found from the circumstances . . . ." McGregor v. United States, 134 Fed. 187, 195-98 (4th Cir. 1904). If similar reasoning is pursucd in the speech situation, good motives for the delivery of a speech would be irrelevint if compensation prompted its delivery.

71. See Note, The Void-for-Vagueness Doctrine in the Supreme Court, 109 U. PA. L. REv. 67,88 (1960).

72. Goldstein, Conspiracy to Defraud the United States, 68 YaLe L.J. 405,406 (1959).

73. Id. at 407-12.

74. Such an expansion of the privilege would make its scope no broader than it already is in civil actions for libel and slander. See text accompanying note 7, supra.

75. Gross, The Legislative Struggle 136-37 (1953). 
concrete acts. The conflict of interest statute (and its modern successor) ${ }^{76}$ allows conviction for an agreement to receive compensation even when the bribed service has not been performed and even when consideration has not passed. ${ }^{77}$ Thus the statute leaves the jury free to convict essentially upon evidence of intent only. Standards for proof of intent are rather uncertain, and a Congressman might fear legitimately that honest conduct could be misinterpreted. Every conversation with a constituent interested in having his Congressman support legislation or urge change in executive policy could be suspect.

Although the Fourth Circuit would have been justified in holding that existing criminal statutes afford juries, and consequently prosecutors, latitude inconsistent with the free speech or debate clause, the court was not justified in finding a comprehensive constitutional prohibition on bribery prosecutions. This holding prevents Congress from providing for any prosecution of bribed speech, irrespective of the degree of precision with which Congress defines the elements of the offense. Admittedly, the difficulty of defining bribery in the legislative context is greater than in the area of executive conflict of interest. ${ }^{78}$ The indispensability of campaign funds and the pressures of constituents combine to blur the boundary between legitimate and illegitimate action. ${ }^{79}$ However, the definition of the offense of bribery need not rest upon vague evidentiary foundations. A precise definition of bribery could require proof of a concrete and complete transaction. Conviction of the offense could be predicated upon proof of the passage of consideration and the performance of a service in addition to an agreement binding the bribee to act. The possibility of a tight definition of bribery which would sharply reduce discretion afforded

76. 18 U.S.C. $\$ 203$ (1964). The statute imposes punishment on an official who "recives or agrees to receive ... any compensation for any services rendered or to be rendered." The Government could have indicted Johnson for the speech under the bribery statute, 18 U.S.C. $\S 205$ (1958), which has since been incorporated into a more general statute applying to all federal officials, 18 U.S.C. $\S 201$ (1964). But these statutes present vagueness problems similar to those encountered under the conflict of interest provision.

77. The statute seems so plain on its face that it would be difficult to read it otherwise, although no convictions have been found in which defendants performed neither the act of rendering services nor that of receiving compensation. See generally MLANivic, Federal CoNFIICT OF INTEREST LAT 38-39, 45 (1964).

78. See Subcomm., Senate Comm. on Labor and Public TVelfare, 820 Cong., lst Sess., Report on Ethical Standards in Government 19-33 (Comm. Print 1951); and with particular reference to the problems of legislators. Dougras, Etrics in Govervisent 64-96 (1952).

79. The problem has not escaped congressional concern. E.g., Hearings Before the Special Committee to Investigate Political Activities, Lobbying, and Campaign Contributions, 84th Cong., 2d Sess. 980-82 (1956-57). 
under existing statutes indicates that there need not be an absolute immunity to bribery prosecutions.

The fourth argument advanced by the Court of Appeals-the possibility of abuse of executive discretion through the initiation of groundless indictments-also fails to justify its sweeping rationale. Although a more precise definition of the offense would not affect a prosecutor's discretion to initiate groundless indictments, this irreducible minimum of prosecutorial discretion does not justify the court's construction of the speech or debate clause. First, the threat of criminal prosecution is a clumsy device for intimidating Congressmen. More subtle techniques are available such as the threat to disclose publicly the peccadillos of a Congressman's private life. Second, there is no tradition of congressional immunity from criminal prosecution. ${ }^{80}$ Third, administrative officials are reluctant to tangle with Congress. men, even where the enforcement of criminal statutes is involved. ${ }^{\text {s1 }}$ Finally, the threat of a groundless indictment upon a Congressman's chances of reelection should not be exaggerated.82 The inevitable discretion of a prosecuting official to initiate groundless prosecutions is present under every statute and it appears doubtful that this discretion is an effective deterrent to honest congressional speech.

The fifth round of decision relied upon by the Fourth Circuit-the availability of legislative sanctions-justifies neither the result in the particular case nor the court's sweeping rationale. The availability of legislative sanctions does not imply that these sanctions are exclusive. ${ }^{83}$

80. The spectre of a runaway executive seems never to have been raised. Unitcd States v. Quinn, 141 F. Supp. 622 (S.D.N.Y. 1956) (granted motion for acquittal on the ground that the defendant, as a member of Congress, did not know of the receipt of fees by his law firm). Burton v. United States, 202 U.S. 344 (1906) (upheld the conviction of a Senator for accepting compensation to intervene before the Post Office Department); United States v. Dietrich, 126 Fed. 676 (C.C.D. Neb. 1904) (held that statute did not prevent senator-elect from accepting payment to procure office for another). In May v. United States, see supra note 8, a court upheld the conviction of the Chalr. man of the House Armed Services Committee for accepting compensation to intervene before the War Department in an effort to obtain contracts for his patron. The indictment of a prestigious committee chairman certainly strikes at the "independence" of that official in most direct fashion; yet the Court in May declined to invoke the hobgoblin of a runaway executive.

81. Gross, op. cit. supra note 75, at 41 .

82. Although Johnson was indicted three weeks before the general election of 1962, he was barely defeated. Brief for Appellant, p. 7, United States v. Johnson, 397 F.2d 180 (4th Cir. 1964). An indictment may even serve to rally a Congressman's constitucnts to his side, as illustrated by the classic case of James Michacl Curley. Wilson, Congkess: CORRUPTION AND COMPROMISE 75-79 (1951).

83. U.S. ConsT. art. I, § 5, cl. 2 provides: "Each House may determine the Rules of its Proceedings, punish its Members for disorderly Behavior, and, with the Concurrence 
In fact Congress itself hesitates to exercise its powers of censure or of expulsion $^{84}$ and instead provides for judicial proceedings. This preference is easily understood. A trial in a court affords the accused Congressman the benefit of constitutional guarantees. When a legislative body sits in judgment, the definition of the offense, the standard of proof, $^{85}$ and the propriety of a given procedure ${ }^{50}$ is a matter for its discretion. Moreover, there exists always the inevitable political coloration assumed by any legislative effort to discipline its members, ${ }^{87}$ undoubtedly persuaded the Congress to provide a judicial forum. ${ }^{88}$

of two-thirds, expel a Member." Counsel for a United States Senator convicted of accepting compensation to intervene before an executive agency unsuccessfully urged that this clause implied an exclusive jurisdiction. Burton v. United States, 202 U.S. 344 (1905). The Court, while conceding that a senator could not be forced to vacate his seat upon conviction, declared:

there is no necessary connection between the conviction of a Senator of a public

offense prescribed by statute and the authority of the Senate .... .

Id. at 367. Similarly, although Congress invokes the aid of the courts to punish recalcitrant witnesses, it retains its own sanction of contempt proceeding. Jurncy v. MacCracken, 294 U.S. 125, 151 (1935).

84. Congress has tried expulsion only eighteen times and most of these attempts were directed against Southern Congressmen in the days immediately preceding World War II. Oppenheim, Congressional Free Speech, 8 LoyoLA L. REv. 1, 27 (1956). Perhaps because of a reluctance to disrupt the atmosphere of the "club," Congressmen have, for the most part, scrupulously refrained from investigating allegations of corruption in their midst. Wirson, op. cit. supra note 82, at 3. The House of Representatives has usually declined to act even against members indicted for felony and indecd has not hesitated to appoint them to committees. H.R. Doc. No. 374, 88th Cong., $2 \mathrm{~d}$ Sess, Cosstitution, JeFferson's MLANUAL and Rules of the House of Representattives 133 (Dechslet ed. 1965). And while Rule VIII of that chamber provides that crery representative "shall vote on each question put, unless he has a personal or pecuniary interest in the event of such question," H.R. Doc. No. 374 , supra at 318 , only on very rare occasions has the Speaker enforced the rule, nor have members sought to extend its force to official action other than voting. Gross, op. cit. supra note 74 , at 40 .

85. "The right to expel," the Supreme Court has asserted, "extends to all cases where the offense is such as in the judgment of the Senate is inconsistent with the trust and duty of a Member." In re Chapman, 166 U.S. 661, 669.70 (1897).

86. In a 1795 contempt of Congress proceeding before the House, members opined "there was no obligation to permit counsel although it might be done as a favor." 2 Hinds, PReCEDENTS OF the House of Representatives $\$ 1601$, at 1050 (1907). Congtessional jurors with predisposed views are not subject to challenge. Id. at $\$ 1618$, at 1086 . And today television cameras create additional hazards for the accused whereas they are not permitted in federal courts in criminal proceedings. FED. R. Crm. P. 53. See also A.B.A. Canons of Jud. Etmos 35 . For a contrast between the judicial and legislative procedure see Boldt, Should Canon 35 of the Code of Judicial Ethics Be Revised?, 16 F.R.D. 83 (1956); Tinkham, The Bar and Canon 35, 19 F.R.D. 19 (1957).

87. The late President Kennedy noted that in the most famous legislative trial held in this country, the impeachment of Andrew Johnson, "The chicf interest was not in the trial or the evidence, but in the tallying of votes necessary for conviction." KENivenr. Profmes in Courage 113 (1957).

88. As one senator has written, concerning the handling of legislative corruption, 
Although the Court of Appeals in Johnson would have been justified in dismissing all the counts against Johnson because they were brought under impermissibly vague statutes, the five arguments advanced by the Fourth Circuit do not support its construction of the free speech or debate clause as a comprehensive prohibition on any congressional attempt to subject its members to prosecution for bribery. The Johnson rationale infuses an incongrous dimension into a constitutional privilege designed to promote the independence of legislators.

. . . civil rights will be better safeguarded and criminal justice will be morc stringently applied if Congress encourages the courts and the prosecutors to handle these matters.

Quoted in Wirson, op. cit. supra note 81, at 250. In its recent decision that 504 of the Labor-Management Reporting and Disclosure Act of 1959 amounted to a bill of attainder, the Supreme Court discussed extensively this inherent unsuitability of the legislature as a place of trial. United States v. Brown, 381 U.S. 437, 442-46 (1965). 